\title{
The Commitments Statement: A New Statement for Creditors
}

\author{
*Saeid Jabbarzadeh Kangarlouei ${ }^{1}$, Sherko Hormozi², Rezgar Talebpour Asl ${ }^{3}$, Asghar azizi ${ }^{4}$ \\ ${ }^{1}$ Islamic Azad University, Orumieh Branch, Orumieh Iran \\ ${ }^{2}$ Islamic Azad University, Piranshahr Branch, Iran \\ 3Islamic Azad University, South Tehran Branch, Iran \\ "Islamic Azad University, Miandobbe Branch, Iran \\ *dr_jabbarzadeh@yahoo.com
}

\begin{abstract}
Much has been written lately concerning the failure of several major corporations to report their financial statuses accurately. Enron, Global Crossing, IBM and others have failed to provide accurate information to their investors and to provide full disclosure of liabilities that would influence the valuation. The present paper is focusing on creditors as a main group of accounting information users, which have been neglected, in field of information presentation. To solve this problem we introduce a new financial statement called "the commitments statement". In the beginning, we point out financial reporting goals and users' informational needs. Then, we mention the issue, which creditors' informational needs have not been well provided; and the reasons are explained. We continue with inspection of providing information related to solvency and recognition of financial flexibility of entities. Finally, we introduce "the commitments statement" and explain how to provide this statement. We end with the conclusion section.
\end{abstract}

Key words: Financial reporting, the commitments statement

\section{Introduction}

Financial Reporting Objectives: Financial accountings` final output is financial reports that are used to represent financial information to various users, including both internal users and outsiders. These statements help users evaluate the entity's financial position, performance and financial flexibility. The user needs approach is essentially deductive; if users of financial statements and their required information for decision making are identified, then information in financial statements can be specified in the appropriate form (McCartney, 2004). Much has been written lately concerning the failure of several major corporations to report their financial status accurately. Enron, Global Crossing, IBM and others have failed to provide accurate information to their investors and to provide full disclosure of liabilities that would affect the valuation (Atkinson, 2002). APB4 refers to financial reporting goal as "providing reliable financial information about resources and commitments of a business entity. Hence, financial reporting shows accountability of business entity about its resources which results in evaluation of stewardship responsibility of management and facilitates making useful economic decisions.

In 1973, the Trueblood report determined 12 objectives for financial reporting; which, in fact, are financial statements objectives that determine information users and focus on providing their informational needs. Here we point out some of these objectives in brief. OB 1: "The purpose of financial reporting is to demonstrate information which can be used as the basis of economic decisions." Creditors use financial statements information to decide whether to give their financial resources to business entities or take back resources they had paid to them. Do financial statements really help creditors evaluate the entity's solvency? OB 2, 3: "Financial statements provide information for users who have limited ability and information resources and can't easily access to information they need so that financial statements are their only information resource. And also in the third objective it is mentioned that financial statements objective is to provide useful information for investors and creditors, in order to help them predict, compare and evaluate future potential cash flows toward a business entity." Do financial statements really meet these needs? Do they really help creditors evaluate future potential cash flows? OB10: "Financial statements must provide useful information for prediction process. Financial prediction will be possible when information can enhance reliability of users (focusing on creditors) predictions."

Creditors must make predictions about quality, amount, timing and uncertainties of retrieving resources they have paid to business entities. The most important part of prediction is evaluation of firms` solvency. 
Do financial statements really provide information to make reliable predictions? In November 1978, FASB tried to codify a statute for financial accounting and reporting. This act resulted in appearance of comprehensive guidelines, which eventually determined financial reporting objectives in SFAC NO .1 "financial reporting objectives for business entities". SFAC NO.1 paragraph 34: "Financial statements must provide information for current and potential creditors and other users so that these groups can make sound decisions about granting credit and other similar decisions." In this paragraph, current and potential creditors are introduced as information users, that based on given information decide about giving credit to business entities. Are financial statements able to help creditors make decisions about giving credits to business entities?

SFAC N0.1, paragraph 37: "Financial statements must provide information which helps current and potential creditors and investors and other users judge about amount, timing and uncertainty of future cash flows from dividends, interest earned from sale or redemption of securities and also cash received at maturity of loans." Possibility of liability payment is depended on the ability of firms to generate sufficient amount of money for payment of their liabilities. This judgment needs reliable and relative information. Do financial statements provide such information? SFAC NO .1, paragraph 49: "Financial statements must provide information about the way in which firms earn and consume money, take and repay loans and also about capital expenditures like paying dividends and other payments that the business entity pays from owner's resources; and finally, it provides information about factors which may influence liquidity and financial power of firms." From the True blood report and SFAC, statements we can conclude that creditors are introduced and known as one of two main groups of information users which accounting regime must provide information they need. Do current financial statements provide proper information about how the money is consumed and how loans are repaid? According to what is represented in financial statements, can we claim that creditors are a main group of information users?

\section{Literature Review}

Several studies have examined financial reports users, in different countries, and have determined the creditors as one of the main users (Wallace, 1988; Nicholls and Ahmed, 1995; Abu-Nassar \& Rutherford, 1996; Ngangan et al, 2005). States that information will be useful when it shows real economic position of entities through financial statements (i.e. the balance sheet, the income statement and the cash flow statement); and it is relevant and reliable for users. Frank \& Jesper (2008) showed that the value relevance of accounting information, for various users, has not decreased and it`s still useful for its users. In contrast, some researches claim that current financial reporting is not suitable for "new economy" and therefore changes must occur in this system (Amir \& Lev, 1996; Francis, Schipper \& Vincent, 2002; Richard, 2003).Michael and Laura (1999) suggested that conceptual frameworks serve multiple purposes, such as marketing standards and needs to provide new financial reports to preparers and users. Showed that users heavily depend on information obtained from reports than on advice from stockbrokers or on tips and rumors the historical review shows that the basic objective of financial statements is concerned with providing useful information for economic decision-making.

\section{Theoretical Basis}

Evaluation of solvency - neglecting the creditors: The main responsibility of accounting is to provide informational needs of its users. However, does it really provide information that creditors need? Creditors evaluate the ability of business entity to pay its liabilities through following items:

- Determination of how, when and the amount of commitments which has been paid off by firms.

- Evaluating certainty of retaining credits.

- Prediction of future cash flows, in order to evaluate risk of paid credits.

Current financial statements just represent an imperfect interpretation of business entities ability to repay their liabilities. This interpretation is based on information provided for owners; therefore, creditors analyze some information that is second hand. Basic financial statements are the balance sheet, the income statement, the comprehensive income statement and the cash flows statement. The question is that, which statement does show the ability of a business entity to discharge its liabilities? Here we point out the way that financial statements provide information for users. 
Balance Sheet: The balance sheet shows financial position at a certain date and creditors interpret that suitable financial position may be a sign of good solvency. Usage of financial ratios is another way for creditors, through the balance sheet, to evaluate the ability of a business entity to pay back its liabilities. Quick ratio and current ratio are two main ratios used for this purpose. However, these ratios are general, static, one-dimensional and inattentive to the state of cash flow provision and therefore, are not capable of having a good expository ability. Practically, analyzing solvency based on current financial ratios is not reliable and determinant; and hence cannot play a leading role for users` decisions. On the other hand, the balance sheet has a retroactive standpoint, shows financial position at a point of time in the past year, and is not able to represent information about future solvency of business entities.

Income Statement: The income statement is another significant statement. It represents operating results and profitability of business entities. Following the nature of accounting basis, namely accrual basis, reported income has an accrual nature which may still hasn't been converted into cash; and cash might be used for various purposes such as repaying liabilities. Therefore, income and profitability are information that belongs to owners; and creditors analyses using this information, which represent profitability power of entities, is an irrelevant and defected analyze. It means that they must use information about current activities of the business entity to analyze financing aspects of a business entity, which is greatly probable not to be a reliable analyze.

Cash Flows Statement: The third main financial report is the cash flows statement which shows how cash has been generated and how it's been consumed in a period of time. Therefore, it does not report how, when and how much money has been used to reimburse liabilities and which resources have been used for this purpose. The cash flows statement, alike the balance sheet, has a retroactive approach and shows cash flows in the past period; hence, it doesn't have the ability to represent information which is useful for evaluation of entity's ability to reimburse its liabilities in future period(s). Creditors understanding of this statement will be general so that creditors just understand the existence of cash in the business entity (but it is a retroactive approach) and it does not help in determination of quality, consuming, timing, and uncertainty of cash usage in the business entity. Therefore, by relying on current statements, creditors can`t certainly evaluate quality, timing and amount of money they receive.

Using the balance sheet they just get information on the combination of firms resources which is made up of credits paid by creditors and owners` resources; they get information about the firm`s profitability using the income statement; and also get information about current period cash flows through the cash flows statement. In fact, creditors make predictions about and evaluate firms risk based on information, which has been provided for investors. To trade off between risk and return, potential creditors need certain type of information, which should help them evaluate the firm's solvency. Balance of risk and return is the most important principle in all trading activities. Nevertheless, using current financial statements they do not get information they need for decision-making. According to what was mentioned above, we need to represent a new financial statement to cover those gaps in providing financial statements.

Financial Power-A new concept: When we discuss a business entity`s financial ability, we must consider three general dimensions of the firm, which thoroughly show its financial ability. These three dimensions determine all weaknesses and strengths of the firm in relation with amount, quality and uncertainty of financial resources and their usage, and help users in interpretation of financial information. Determining the firm`s financial power also provides information for analysts` predictions and evaluations. These dimensions include: 1) the ability to finance current operations 2) the ability to reimburse liabilities (solvency) 3) the ability to use investing opportunities. Through financial transactions and events, firms try to provide sufficient cash for their current operations; where cash is probably provided through sale of goods, investments and other assets. Firms to pay back credits they have been paid to use cash that is earned through these activities. This is the second dimension. The probability of having cash to repay received credits by firms, after financing necessary resources for current operations, is called solvency. This issue is of great importance for firms' creditors. Therefore, uncertainty in receiving granted credits, to some extent, increases creditors risk so that they will be reluctant to give credits to the firms. Hence, it is crucial to provide and represent information, which enables creditors, based on competition in capital market for absorbing current credit resources, decide where and to whom they must trust, and consequently help them to have certain investments. 
If firms are able to generate extra resources more than what they need and when vital investment opportunities and / or special occasions exist where there is a threat against survivance of entities, the extra money will be consumed for any of the opportunities/ threatening occasions. This is called the ability to use investing opportunities. It enables companies to face threats and make use of opportunities, the best way they can. Hence, in this article we introduce a new concept, called financial power. Financial power is a combination of three abilities we mentioned above; namely, ability to provide cash, solvency and the ability to use investing opportunities. In fact, provided if information users in capital market are aware of this new concept, they will make more accurate predictions and evaluations and their decisionmaking process will be more probable to come true and definitely more certain. Financial power concept talks about how resources have been provided and consumed, and how we can use these resources more productively. As a new statement, the statement of commitments provides information about three various dimensions of firms' financial ability. 1) How financial resources have been provided (providing cash), 2) how these resources are used for reimbursement of liabilities (solvency) 3) the ability to use investing opportunities in the case that resources exceed commitments.

Figure1: Financial power and its aspects

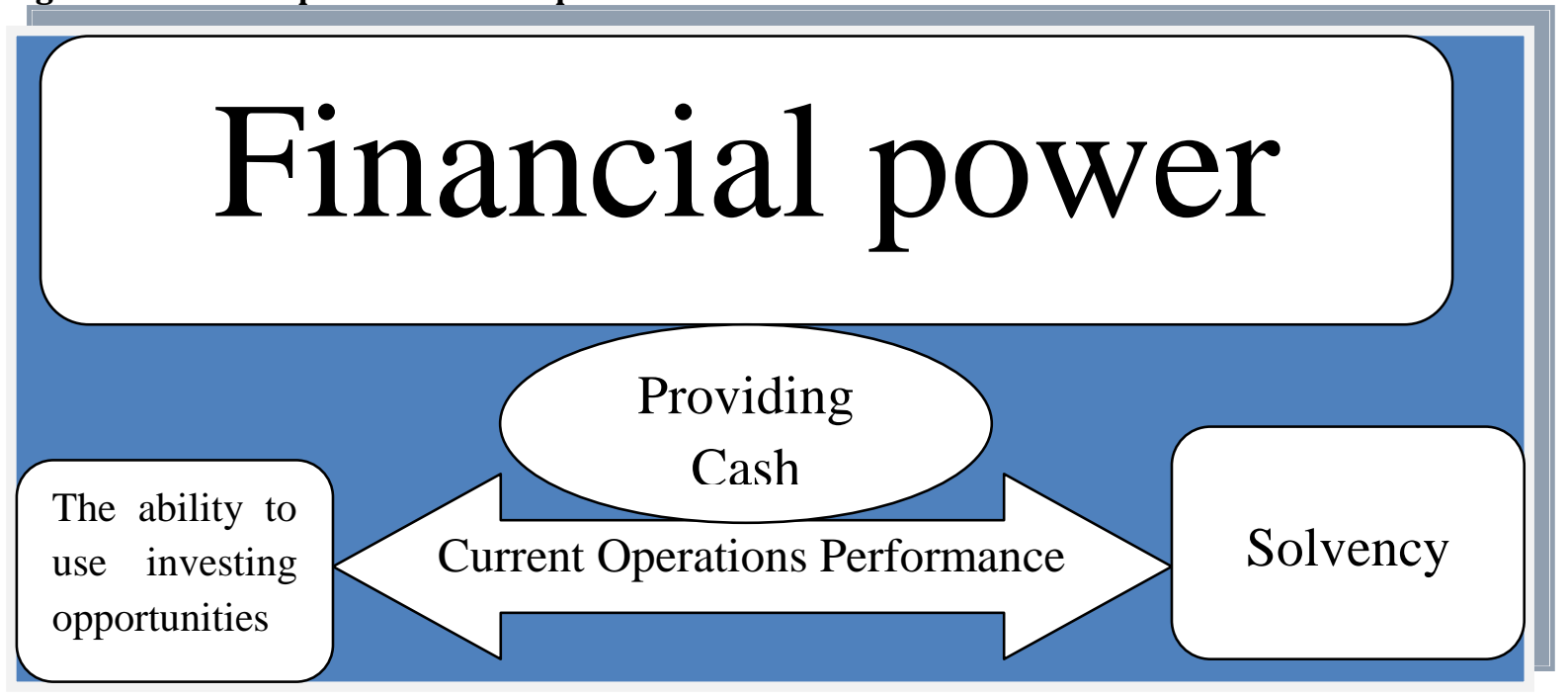

The ability to use investing opportunities: The ability to provide required information for users is a necessity for accounting system if it still wants to survive in competing field of information providing. Hence, attempting to recognize new needs and providing these new needs are strategies which accounting system must pay special attention to. Assessment of the ability to use investing opportunities by information users is essential for evaluation of solvency. Determining existence of the ability to use investing opportunities even helps users in prediction of the firm`s perspective and its future return. Therefore, providing this information plays a great role in users' general evaluations, but by looking into financial reporting system, we cannot find any information, which is related to the ability of using investing opportunities by the firm. Therefore it's essential to provide such information. This ability is interpreted as the skill of firms to match and encounter unpredicted opportunities or changes in current conditions. On the other hand, it is defined as the ability of firms to use opportunities, solve, and manage threats they face. In fact, this ability is firms ' power to act effectively to change amount and timing of cash flows so that the business entity can react to unexpected events and opportunities.

It enables firms to make use of unexpected opportunities and survive in periods of low or negative cash flow from operating activities. Providing cash, solvency and the ability to use investing opportunities exhibit three dimensions of firms' financial power. Providing cash flow, which guaranties current operating cycle, is a sign of the business entities ability to make payments and investments. Solvency refers to the ability of firms to determine timing, quality and risk of providing credit. However, the ability to use investing opportunities, besides considering cash flows and solvency, evaluates firms' flexibility to trading and economic changes. In this article, we introduce the commitments statement and through its information, we assess the ability of firms to use investing opportunities.

The commitments statement: Definition: the commitments statement is a future-oriented report that, by emphasizing on financial power concept, shows the solvency of a business entity at a certain period. In order to help creditors evaluate possibility of credit reimbursement and measure the risk of credits paid 
to the firms, this statement explains the quality, timing, amount and resources that are being used to pay back credits to creditors. In the process of presenting the commitments statement, first we should recognize commitments and their maturity. To classify the commitments based on their maturity, we have determined six different periods. Then, we determine resources, which are available to fulfill these commitments and report them according to the maturity of each class. In other words, we determine how each liability resource must be provided. Times are classified as:

- Three month period;

- Three to six month period;

- Six month to one year period;

- One year to two years period;

- Two years to five years period;

- Over five-year period.

The justifying logic behind this classification is explained below:

- Determining and dividing all resources according to their nature and root;

- Determining and dividing all commitments according to their nature and maturity;

- Dividing resources according to their timing classification;

- Dividing commitments according to their timing classification;

- Dividing commitments and resources according to the entity`s activities in different time periods

- Classification according to principles and periods used for suitable assessments;

- A kind of classification which facilitates analyses for all type of creditors;

- Classification based on different timing claims on the firm.

\section{Definitions}

Resources: In the commitments statement, resources and their time of conversion to cash, based on six periods mentioned above, must be defined. So, resources are classified according to one of those periods:

- Resources used to repay three - month commitments: this class includes cash and resources that are probable to be converted into cash in less than three months. Besides cash, ready to market investments and trading accounts receivable are included in this class, too.

- Resources used to fulfill three to six - month commitments: these resources include items that are possible to be available for repayment of liabilities in six months. Examples include accounts and notes receivable and short-term investments.

- Resources used for reimbursement of six - month to one-year commitments: firms can convert these resources into cash in a time of six months to one year and be used to reimburse liabilities. This group includes materials and goods inventories, investments etc.

- Resource used for fulfillment of one-year to two - year commitments: this group includes resources that are expected to be available for repayment of liabilities, after a year and up to two years. These resources include long-term investments and some of intangible assets.

- Resources used to fulfill two - year to five - year commitments: firms can convert these resources into cash at a period of two years to five years. Examples are fixed tangible assets and long-term investments.

- Resources used to repay over five years commitments: after being converted into cash, these resources will be used to discharge long-term liabilities. This group generally includes fixed tangible assets.

\section{Commitments}

- Three -month commitments: these are commitments incurred in the first quarter of fiscal year, such as accounts and notes payable.

- Three to six - month commitments: the maturity of these commitments, from the beginning of the year, is between three to six months, such as notes and accounts payable, tax reservation...

- Six- month to one-year commitments: these commitments include liabilities that firms should pay in the second half of the fiscal year. Examples are tax reservations, dividends payable, loans received and current share of long- term liabilities.

- One-year to two-year commitments: the maturity of these liabilities is more than one year and less than two years. Examples include long-term accounts and notes payable.

- Two to five-year commitments: these commitments must be discharged in a time of two to five years. Some of long-term loans are classified in this group. 
- Over five-year period commitments: the maturity of these commitments is more than five years. Long term bank loans and employees compensation reservation, are usually classified here.

After classifying the commitments, in order to determine how cash must be consumed for commitments repayment, we classify resources used for this purpose. Assume that a firm must discharge a liability in three forward months, but it cannot provide enough money to pay this liability back. Therefore, creditors conclude that this firm does not have a good ability to reimburse its liability (weak solvency), although the firm might be able to repay its liability in six future months. According to what was stated above, creditors could measure firms' ability to pay its liabilities in different periods. For instance, a firm might not be able to fulfill its short term liabilities, but it`s able to reimburse its long term liabilities and vice versa.

Preparing the commitments statement: To represent the commitments statement, it is necessary to pass through four steps.

- Determine three-month commitments and resources used to discharge these commitments. The result is mentioned as net three-month resources / commitments, whichever is more. If resources exceed commitments, the result is net three - month resource and vice versa.

- The net commitments / resources resulted from the first step, are added to three to six - month commitments / resources. Then, similar to the first step, commitments and resources are opposed and the net result will be computed.

- The process in the second step will be repeated for other commitments and resources.

- In the final step, we show owners` equity, which is firms' liability to the owners, and it must be equal to net resources or net commitments.

Mokrian Corporate The Commitments Statement For the period ended to Dec 312009

\begin{tabular}{|c|c|c|c|c|}
\hline Resources & & commitments & & $\begin{array}{l}\text { Net } \\
\text { resources } \\
\text { (commitm } \\
\text { ents) }\end{array}$ \\
\hline \multicolumn{5}{|l|}{ Three- month period } \\
\hline trading accounts receivable & $x \times x$ & Notes payable & $x \times x$ & \multirow{3}{*}{$x \times x$} \\
\hline Ready to market investments & $\begin{array}{l}x \times x \\
x \times x \\
\end{array}$ & Other three-month payables & $\underline{x \times x}$ & \\
\hline $\begin{array}{l}\text { Total of three-month resources } \\
\text { Three to six- month period: }\end{array}$ & $x \times x$ & Total of three-month commitments & $x \times x$ & \\
\hline Net three-month resources & $x \times x$ & Net three-month commitments & $x \times x$ & \multirow{11}{*}{$x \times x$} \\
\hline Receivable notes & $x \times x$ & Notes payable & $x \times x$ & \\
\hline Short term investment & $x \times x$ & Tax payable & $x \times x$ & \\
\hline Short term received loans & $\underline{x \times x}$ & Other three to six-month payables & $\underline{x \times x}$ & \\
\hline Total & $x \times x$ & total & $x \times x$ & \\
\hline \multicolumn{4}{|l|}{ Six month to one year period: } & \\
\hline Net resources until six month & $x \times x$ & Net six month commitments & $x \times x$ & \\
\hline Materials and goods inventories & $x \times x$ & Dividends payable & $x \times x$ & \\
\hline Other short term investments & $x \times x$ & Short - term loans payable & $x \times x$ & \\
\hline Current in advance payments & $\underline{x \times x}$ & Current share of long term & $\underline{x \times x}$ & \\
\hline Total & $\overline{x x x}$ & $\begin{array}{l}\text { liabilities } \\
\text { total }\end{array}$ & $\overline{x \times x}$ & \\
\hline \multicolumn{5}{|l|}{ One year to two years period: } \\
\hline Net one-year resources & $x \times x$ & Net one year commitments & $x \times x$ & \multirow{10}{*}{$x \times x$} \\
\hline Long-term investments & $x \times x$ & Long-term accounts payable & $x \times x$ & \\
\hline Equipments and plants & $\underline{x \times x}$ & Long term notes payable & $\underline{x x x}$ & \\
\hline total & $x \times x$ & Total & $\overline{x \times x}$ & \\
\hline Two years to five years period & & & & \\
\hline Net two-year resources & $x \times x$ & Net two years commitments & $x \times x$ & \\
\hline buildings & $x \times x$ & long-term financial credits & $x \times x$ & \\
\hline Long term investments & $x \times x$ & Long-term loans & $\underline{x x x}$ & \\
\hline Other assets & $\underline{x \times x}$ & & & \\
\hline Total & $\overline{x \times x}$ & Total & $x \times x$ & \\
\hline
\end{tabular}


Five-year and longer periods: Net five-year resources

Land

Intangible assets

Total

\section{$x \times x$ \\ $x \times x$ \\ $\frac{x \times x}{x x x}$ \\ $\overline{x x x}$}

\author{
Net five-year commitments \\ Long-term bank loans \\ Compensation reservation \\ Total
}

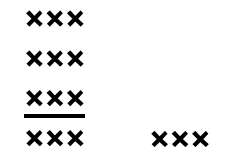

Net resources(commitments) of the firm The owners`equity

Financial power analysis based on the commitments statement

Analyses based on the commitments statement is classified in three levels:

- Time period analyses;

- Analyzing financial ratios;

- Analyzing the present value of resources and commitments.

\section{Financial power analysis based on the commitments statement}

Analyses based on the commitments statement is classified in three levels:

- Time period analyses;

- Analyzing financial ratios;

- Analyzing the present value of resources and commitments.

Since the information related to the three first periods of the commitments statement are closer to the firm`s activities, it is of more importance in comparison to the three second periods. Hence, evaluations based on the three first periods are actual and more probable to happen.

Analyzing times: In the first step of analyses, resources, which could be converted to cash, are taking into account. According to time segments and resources available in these periods, users (especially creditors) analyze the firm`s ability to provide cash. Analyzing the first aspect of financial power is provided through resources column. Ratios extracted from the commitments statement also help in evaluation of this aspect. Then, the commitments are evaluated based on the commitments' maturity; creditors decide whether to give credits to the firm or not. For instance, if a business entity requests a one-year loan and the firm has many loans in the period of six month to one-year, and creditor accepts the request, in fact it has undertaken too much risk. Thus, evaluating the second aspect of financial power (solvency) is possible using the commitments column and different times. In the last and most important part of time period analyses, the ability to use investing opportunities is evaluated. In this step, for each of the six periods, net resources or commitments is determined. In periods, which there are net resources, credit risk is low; in periods, which there are net commitments, credit risk is high .Therefore, potential creditors must consider this risk and their analyses must be based on these findings.

Analyzing the commitments statement's financial ratios: In the second step, we calculate some ratios which can be used for assessment of the business entity`s ability to provide cash, its solvency and also its financial flexibility .These ratios are introduced here.

Cash to current assets or total of assets $=\frac{\text { cashprovidedincurrentperiod }}{\text { currentassets totalofassets }}$

The above ratio shows firm`s ability to provide cash in different periods of time. This ratio varies among different industries and it also depends on investment policies and the firm`s goal. For a period of three month, if this ratio is high, it shows high ability of the firm to generate cash in short run.

Net resources to current assets ratio= $=\frac{\text { netresources }}{\text { current assets total assets }}$

This ratio exhibits the business entity`s ability to provide cash after discharging all its commitments. Calculating this ratio is possible when resources excess the commitments .If this ratio is high, it represents high financial flexibility of the firm. 
Net resources to investment opportunities ratio $=\frac{\text { netrsesources }}{\text { investmentopportunities }}$

Resources to investment opportunities ratio $=\frac{\text { rsesourcesindifferentperiods }}{\text { investmentopportunities }}$

These ratios represent the ability of firms to provide financial resources in periods that good investment opportunities exist. Net resources to investing opportunities ratio also exhibits the firm`s ability to make proper investments after fulfillment of commitments at a certain period of time.

Analyzing the present value of resources and commitments: The third step is to discount net resources and $\backslash$ or commitments for different periods in the commitments statement. We discount their numbers using market interest rate. Then, we match discounted resources and discounted commitments; if discounted resources exceed discounted commitments, we can claim that the firm has a high solvency . The excess of resources over commitments also means that there is sufficient cash available in time of necessity .Hence, provided if resources are positive, it shows high financial flexibility of a firm

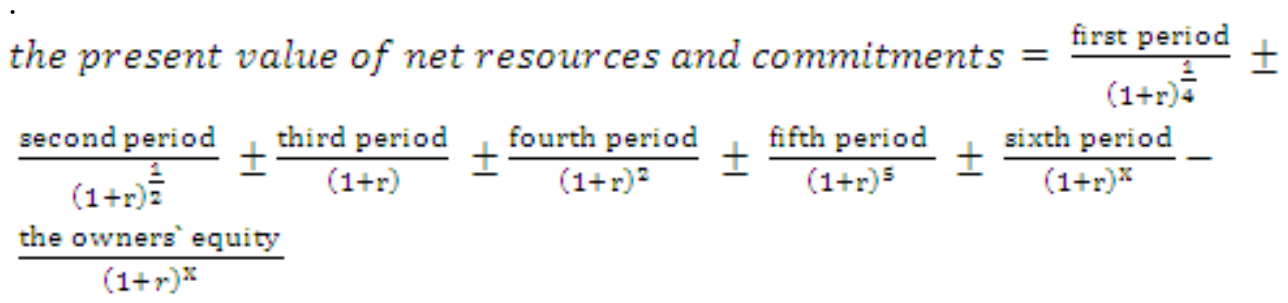

The discounted values of resources are added up together and will be subtracted from discounted commitments and the result is net discounted resources or commitments. Since the sixth time does not cover a clear time confine, to discount net resources in this period and the owners' equity, we consider the same times. Therefore the impact of the sixth period's discounted value and the owner's equity is unimportant and could be neglected. The net present value of resources and commitments shows the firm`s financial power, regarding the time value of cash. Here we represent an example for more explanation.

Mokrian corporate has given you this information:

\begin{tabular}{llll} 
Cash & 10000 & Three-month accounts payable & 45000 \\
Three-month Accounts receivable & 20000 & Six-month Notes payable & 10000 \\
Six-month Accounts receivable & 30000 & Tax reserves & 15000 \\
One-year notes receivable & 15000 & Nine-month dividends payable & 30000 \\
Short-term investment & 20000 & One-year loans & 25000 \\
Materials and goods inventory & 50000 & Current share of one-year liabilities & 35000 \\
Long-term investment & 30000 & 16-month accounts payable & 15000 \\
Machinery & 120000 & 18- month Notes payable & 40000 \\
Land & 120000 & 26-month loans & 40000 \\
Building & 80000 & Six-year loans & 50000 \\
Intangible assets & 60000 & Compensation reservation & 70000 \\
Other assets (salable in 20000) & 40000 & Owners equity & 220000 \\
\hline
\end{tabular}

Required: Prepare the commitments statement for Mokrian corporate 


\begin{tabular}{|c|c|c|c|c|}
\hline Resources & & Commitments & & $\begin{array}{l}\text { Net resources } \\
\text { (commitments) }\end{array}$ \\
\hline Three months: & & & & \\
\hline Cash & 10000 & & & \\
\hline Trading accounts receivable & $\underline{20000}$ & accounts payable & (45000) & \\
\hline Total & 30000 & Total & $(45000)$ & $(15000)$ \\
\hline Three to six-month period: & & & & \\
\hline & & Net three-month commitments & $(15000)$ & \\
\hline Accounts receivable & 30000 & Notes payable & $(10000)$ & \\
\hline Short-term investment & 20000 & Tax payable & $(15000)$ & \\
\hline Total & 50000 & Total & $(40000)$ & $(10000)$ \\
\hline $\begin{array}{l}\text { Six month to one year } \\
\text { period: }\end{array}$ & & & & \\
\hline Net resources until six month & 10000 & Dividends payable & $(30000)$ & \\
\hline $\begin{array}{l}\text { Materials } \\
\text { inventories }\end{array}$ and $\quad$ goods & 50000 & Short - term loans payable & $(25000)$ & \\
\hline Notes payable & 15000 & $\begin{array}{l}\text { Current share of long term } \\
\text { liabilities }\end{array}$ & $(35000)$ & \\
\hline Total & 75000 & Total & $(90000)$ & 15000 \\
\hline & & Net one year commitments & $(15000)$ & \\
\hline Long-term investments & 30000 & Long-term accounts payable & $(15000)$ & \\
\hline Equipments & 60000 & Long term notes payable & $(40000)$ & \\
\hline Total & 90000 & Total & $(70000)$ & 70000 \\
\hline Two to five-year period: & & & & \\
\hline Net two-years resources & 20000 & & & \\
\hline Buildings & 80000 & & & \\
\hline Plants & 60000 & & & \\
\hline Other assets & 20000 & long-term financial credits & $(40000)$ & \\
\hline Total & 180000 & Total & $(40000)$ & 140000 \\
\hline Five-year and longer periods: & & & & \\
\hline Net five-year resources & 140000 & & & \\
\hline Land & 120000 & & & \\
\hline Intangible assets & 60000 & Long-term bank loans & $(50000)$ & \\
\hline Other assets & 20000 & Compensation reservation & $(70000)$ & \\
\hline Total & 340000 & Total & $(120000)$ & 220000 \\
\hline $\begin{array}{l}\text { Total } \\
\text { resources(commitments) }\end{array}$ & & & & 220000 \\
\hline The owners` equity & & & & 220000 \\
\hline
\end{tabular}

\section{Analyzing the ratios}

\section{1) Cash to current assets ratio in different periods:}

Cash to current assets ratio $=\frac{\text { cash provided in current period }}{\text { current assets }}$

Three-month cash to current assets ratio $=\frac{30000}{145000}=0.2$

Six-month cash to current assets ratio $=\frac{50000}{145000}=0.34$

Six-month to One-year cash to current assets ratio $=\frac{75000}{145000}=\mathbf{0 . 5 1}$

The above ratio shows the ability of the firm to provide cash in future short periods. In case that this ratio, in three months and 3-6 months periods, is high, it`s a sign of high ability to convert current assets to cash in the near future. 


\section{2) Cash to total of assets ratio:}

Cash to total of assets ratio $=\frac{\text { cash provided } \text { in different periods }}{\text { total of assets }}$

Six-month to One-year cash to total of assets ratio $=\frac{30000}{595000}=0.05$

Six-month cash to total of assets ratio $=\frac{50000}{595000}=0.08$

Three-month cash to total of assets ratio $=\frac{75000}{595000}=0.12$

One-year to two-year cash to total of assets ratio $=\frac{90000}{595000}=0.15$

Two-year to five-year cash to total of assets ratio $=\frac{180000}{595000}=0.3$

More than five - year cash to total of assets $=\frac{340000}{595000}=0.57$

In capital-intensive companies, the above ratio is very higher in longer periods compared to shorter ones. In labour intensive ones, which apply less long term investments, this ratio is also significant in short periods. This ratio shows prompt ability of converting total assets to cash. The above ratio shows the ability of the company to convert part of assets into cash.

\section{3) Net resources to current assets ratio:}

Net six-month to one year resources to current assets ratio $=\frac{10000}{145000}=0.06$

The above ratio which is only calculated for the first three periods (provided if resources exceed commitments) shows resources which are available in the next year and can be considered as the ability of the firm to use investing opportunities. If this ratio is high, it shows that the firm can provide necessary cash for short-term profitable investment opportunities. It also shows financial strength of the firm.

\section{4) Net resources to total of assets ratio:}

Net resources to total of assets ratio $=\frac{\text { net resources }}{\text { total of assets }}$

Six-month to One-year net resources to total of assets ratio $=\frac{10000}{595000}=0.016$

One-year to two-year net resources to total of assets ratio $=\frac{20000}{595000}=0.033$

Two-year to five-year net resources to total of assets ratio $=\frac{140000}{595000}=0.23$

Five-year and more net resources to total of assets ratio $=\frac{220000}{595000}=0.36$

This ratio depicts the ability of the firm to use investing opportunities if all assets are used for opportunities or for the purpose of encountering threats. If it is high, it shows high financial power of the firm.

\section{5) Net resources to investing opportunities ratio:}

Net resources to investing opportunities ratio $=\frac{\text { net resources }}{\text { investing opportunities }}$

Six-month to One-year net resources to investing opportunities ratio $=\frac{10000}{50000}=0.2$

To finance all investing opportunities, the above ratio must be more than one. This ratio is 0.2 for Mokrian Company. It means that they only can use twenty percent of their investing opportunities.

One-year to two-year net resources to investing opportunities ratio $=\frac{140000}{80000}=1.75$

Investment in a project like A is possible for the company. Hence, considering the ratio and excess of resources over commitments, the company can use opportunities it faces. 
Analyzing the present value of resources and commitments

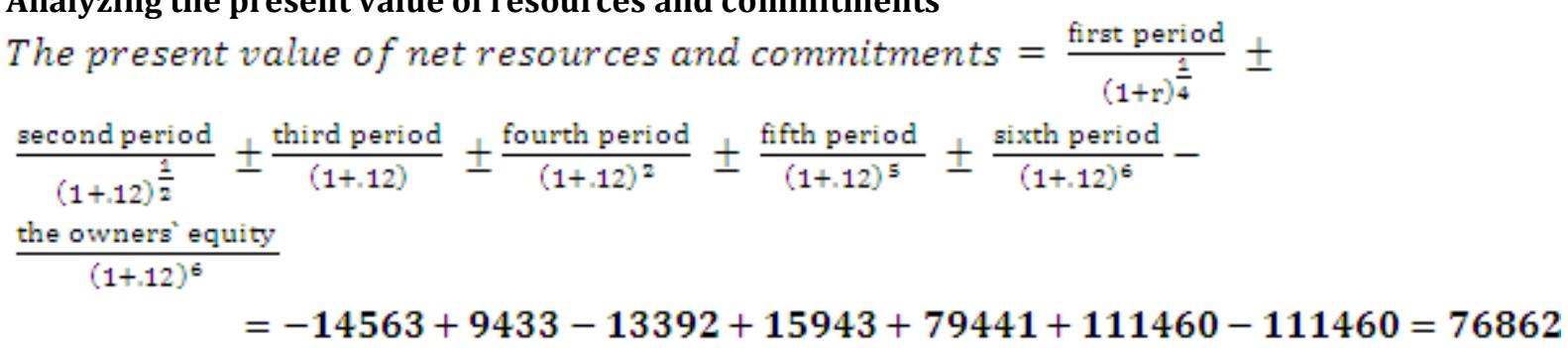

As we could see, the discounted value of the sixth period`s resources and the owner`s equity don`t have any role in determination of the present value of resources and commitments. The present value of resources and commitments shows financial strength of the company, considering the time value of money. Since in our sample company, the resources exceed the commitments, the present value of the resources is positive.

\section{Summary and Conclusion}

Accounting is a system using a process called "financial reporting' provides information for its users. Among users, creditors which are a main group of accounting information users, using current financial statements can't evaluate the ability of firms to reimburse their liabilities. Therefore, to provide such important information "the commitments statement", that shows the ability of business entity to pay back its liabilities, is prepared. The information in the commitments statement is used by creditors to evaluate the business entities' ability to reimburse liabilities and appraise uncertainties about retaining credits paid to the firms (credit risk); and entering such information in their decision-making models helps them to make more effective decisions which are proportionate to their relative risk and return. The commitments statement and its analyses provide valuable information about financial power and solvency of firms and their credit risk.

\section{References}

Abu-Nassar, M. \& Rutherford, B, A. (1995). Preparer's attitudes to financial reporting in less developed countries with moderately sophisticated capital markets: The case of Jordan. The International Journal of Accounting, 30(2), 129-138.

Atkinson, S. A. (2002). Ethics in financial reporting and the corporate communication professional. Corporate Communications: An International Journal, 7(4), 212-218.

Amir, E. \& Lev, B. (1996). Value-relevance of nonfinancial information: The wireless communications industry. Journal of Accounting and Economics, 22(1-3), 3-30.

Francis, J., Schipper, K. \& Vincent, L. (2002). Earning announcements and competing information. Journal of Accounting and Economics, 33, 13-342.

Claire, M. (2003). Financial reporting on the Internet by leading Japanese companies. Corporate Communications. An International Journal, 8(1), 23 - 34.

Frank, T. \& Jesper D, S. (2008). Has financial statement information become less relevant? Longitudinal evidence from Denmark. Journal of management, 24(4), 375-387.

Michael, P. \& Laura, S. (1999). The conceptual underwear of financial reporting. Accounting, Auditing \& Accountability Journal, 12(4), 489 - 501.

Ngangan, K., Saudagaran, S, M. \& Clarke, F, L. (2005). Cultural influences on indigenous users' perception of the importance of disclosure items: Empirical evidence from Papua New Guinea. Advances in International Accounting, 18, 27-51.

Nicholls, D. \& Ahmed, K. (1995). Disclosure quality in corporate annual reports of non-financial companies in Bangladesh. Research in Accounting in Emerging Economies, 3, 149-170.

Richard, B. (2003). The revolution ahead in financial reporting: reporting financial performance. Balance Sheet, 11(4), 19-23.

McCartney, S. (2004). The use of usefulness: An examination of the user needs approach to the financial reporting conceptual framework. Journal of Applied Accounting Research, 7(2), 52 - 79.

Wallace, R. S. O. (1988). Corporate financial reporting in Nigeria. Accounting and Business Research, 18, 352-362. 